\title{
Spatial and temporal distribution of coloured dissolved organic matter in a hypertrophic freshwater lagoon
}

\author{
Diana VAIČIŪTĖ,${ }^{1 *}$ Mariano BRESCIANI, ${ }^{2}$ Marco BARTOLI,${ }^{1,3}$ Claudia GIARDINO,${ }^{2}$ Martynas BUČAS
}

${ }^{1}$ Coastal Research and Planning Institute, Marine Science and Technology Centre, University of Klaipėda, Lithuania; ${ }^{2}$ Optical Remote Sensing Group, CNR-IREA, Milan, Italy; ${ }^{3}$ Department of Environmental Science, University of Parma, Italy

*Corresponding author: diana.vaiciute@jmtc.ku.lt

\begin{abstract}
A dataset of 224 Medium Resolution Imaging Spectrometer (MERIS) full resolution satellite images were processed to retrieve the concentration of coloured dissolved organic matter (CDOM) in a hypertrophic estuary (Curonian Lagoon, Lithuania and Russia). Images covered a period of 7 months, spanning from the ice melting (March) to the late summer (September) of 7 consecutive years (2005-2011). The aim of the study was to analyse the spatial and temporal variations of CDOM, by focusing on the main regulating factors (riverine discharge, sea-lagoon water exchange, water temperature, chlorophyll a, wind) in a large estuary. The working hypothesis is that CDOM distribution may reveal distinct, site specific seasonal patterns. Our results demonstrated that CDOM concentrations at the whole lagoon level were elevated $\left(1.5-4 \mathrm{~m}^{-1}\right)$ and slightly but significantly higher in spring $\left(1.50 \mathrm{~m}^{-1}\right.$ on average) compared to the summer $\left(1.45 \mathrm{~m}^{-1}\right.$ on average). This is due to very different flow of CDOM-rich freshwater from the main lagoon tributary in spring compared to summer. They also highlight macroscopic differences among areas within the lagoon, depending on season, suggesting a complex regulation of CDOM in this system. Significant factors explaining observed differences are the dilution of lagoon water with CDOM-poor brackish water, regeneration of large amounts of dissolved organic matter from sediments and combinations of uptake/release from phytoplankton. CDOM and its variations are understudied due to inherent methodological and analytical difficulties. However, this pool has a demonstrated relevant role in the biogeochemistry of aquatic environments. We speculate that the dissolved organic pool in the Curonian Lagoon has a mainly allochthonous origin in the high discharge period and an autochthonous origin in the summer, algal bloom period. Both positive and negative relationships between CDOM and phytoplankton suggest that pelagic microalgae may act as a source or as a sink of this pool, in particular when inorganic nutrients are limiting.
\end{abstract}

Key words: CDOM, Remote Sensing, MERIS, Curonian Lagoon, Nemunas River, phytoplankton.

Received: January 2015. Accepted: May 2015.

\section{INTRODUCTION}

The light-absorbing coloured fraction of dissolved organic matter (CDOM - Coloured Dissolved Organic Matter), also known as yellow substances, includes compounds of different origin, which mostly consist of humic and fulvic acids (Coble et al., 2004). In natural waters CDOM may be released by primary producers or accumulate during microbial decomposition processes, as a consequence of elevated organic inputs to sediments and incomplete mineralization (Hulatt et al., 2009). Some saprophytic fungi excrete large amounts of phenolic substances which after oxidation and polymerization become humic-like material (Day and Felbeck, 1974).

CDOM has a strong absorption in the ultraviolet (UV) portion of the spectrum and protects phytoplankton, macroalgae and other biota from damaging UV medium wave radiation (Blough and Green, 1995). CDOM itself is eventually destroyed by sunlight, releasing nutrients and trace elements, which sustain the growth of phytoplankton and bacteria (Moran and Zepp, 1997). Therefore, CDOM can represent an important pool of potentially available elements which are generally not considered in mass balances and can sustain primary production (Moran and Zepp, 1997). Various studies demonstrate that mineralization of CDOM can substantially reduce dissolved oxygen in the water column and that its turnover, with associated $\mathrm{N}$ release, may suppress cyanobacterial growth (Bushaw et al., 1996; Beisner et al., 2003; Haggard et al., 2013). Nevertheless, increasing levels of CDOM can reduce the amount and quality of photosynthetically active radiation to phytoplankton and other primary producers (Bidigare et al., 1993). The net effect of CDOM in the functioning of aquatic ecosystem is difficult to predict as the knowledge of its composition, turnover, spatial and temporal variation is poorly explored.

CDOM may be present in large amounts in estuarine ecosystems and play an understudied role in biogeochemistry of lagoons (Bushaw et al., 1996). These loads may have an allochthonous or autochthonous origin and they may undergo different seasonal processes and regulation. Watersheds generate large amounts of dissolved and particulate organic matter, which is generally transported by 
rivers from terrestrial areas to the open sea (Dagg et al., 2004). The organic matter pool transferred to inland waters comprises a wide range of molecules and aggregates, from very refractory low-energy to very labile high-energy, with enhanced oxygen exposure and efficient metabolite exchange (Blair and Aller, 2012). As a net result more refractory forms accumulate, while labile molecules are used first and converted into nutrients and $\mathrm{CO}_{2}$, keeping simultaneously aquatic environments net heterotrophic and very productive systems (Kling et al., 1991). Riverine systems together with organic matter deliver substantial amounts of inorganic nutrients, including nitrogen $(\mathrm{N})$, phosphorus $(\mathrm{P})$ and silica $(\mathrm{Si})$, which have both anthropogenic and natural origin (Gelfenbaum, Stumpf, 1993; Mayer et al., 1998). Nutrients generally accumulate along the terrestrial-sea path, peaking in estuarine systems. Here, as a result of high temperatures and decreased water turbulence, they fuel high rates of primary productivity, including macrophytes, macro and microalgae (Gilbert et al., 2005). These algal blooms result in rapid build-up of newly formed organic matter, often exceeding the grazing control capacity of zooplankton and herbivores in general (Ventelä et al., 2002). The excess of organic matter accumulates in surface sediments as phytodetritus and feeds the mineralization activity of macroinvertebrates and bacteria. The literature reports large fluxes of dissolved organic matter under conditions of low energy yielding electron acceptors (i.e., oxygen deficiency) or under conditions of extremely elevated sedimentation rates (i.e., after large blooms). Here, the decomposition is incomplete and effluxes of dissolved organic dominate over inorganic ones (Lomstein et al., 1998; Aarnos et al., 2012). As a net result sediments may become relevant internal sources of CDOM (Riggsbee et al., 2008; Zhu et $a l ., 2013)$. CDOM may display large seasonal variations and consist of combinations of allochthonous or autochthonous dissolved organic matter; it may undergo a number of transformations depending on a number of local factors such as freshwater inputs, water residence time, quality of organic pool, metabolic efficiency of bacteria, and water temperatures (Nagata, 2008; Astoreca et al., 2009; Matsuoka et al., 2012; Williamson et al., 2014).

In this study we analysed by means of satellite remote sensing the spatial and temporal variability of CDOM in a large eutrophic estuary, the Curonian Lagoon (Lithuania and Russia). Different satellite derived products are available for this system, including a multitemporal detailed analysis of algal blooms, which make possible a large scale study. Some peculiar features make this system as an interesting study site in respect of CDOM. The Curonian lagoon has a main freshwater inlet - the Nemunas River. The river drains a large watershed, hosting wetlands and forests, and discharges annually nearly $23 \mathrm{~km}^{3}$ of CDOM-rich freshwater (Ferrarin et al., 2008). We ex- pected a strong influence of the Nemunas on the distribution of CDOM and its seasonal variation in the Curonian Lagoon, reflecting changes of riverine runoff. Impressive spring blooms of diatoms and summer blooms of cyanobacteria, characterized by elevated spatial and temporal variability, are a common feature of this system (Paldavičienè et al., 2009; Bresciani et al., 2012). Due to connection with the Baltic Sea some areas of the lagoon are exposed to brackish waters, where dilution of the CDOM pool is expected. On the other hand, in remote areas far from the influence of riverine and brackish waters, where accumulation of algal blooms occur, sediments can be relevant autochthonous sources of CDOM (Ferrarin et al., 2008).

We expected in this system a large spatial and temporal variability of CDOM and we analysed the different source of variations, including freshwater discharge, chlorophyll $a$ concentrations, temperature regimes and marine inputs. We speculated on the relevance of phytoplankton degradation as an additional source of CDOM, in particular in the summer period when allochthonous inputs are minimum and large algal blooms occur.

\section{METHODS}

\section{Study area}

The Curonian Lagoon is a large, shallow water body (total area $1584 \mathrm{~km}^{2}$, mean depth $3.8 \mathrm{~m}$ ) located along the south-eastern coast of the Baltic Sea (Fig. 1). The Klaipeda Strait provides the only connection to the Baltic. The mixing of fresh and brackish water masses creates spatially and temporally unstable gradients with salinity ranging from 0 to 7 PSU at a distance up to $20 \mathrm{~km}$ from the sea entrance to the lagoon (Dailidiené and Davuliené, 2008; Environmental Protection Agency, 2010).

The hydrology of the lagoon varies seasonally with changes in river discharge (Ferrarin et al., 2008). The Nemunas River runoff (nearly $23 \mathrm{~km}^{3}$ year ${ }^{-1}$ ) contributes approximately $96 \%$ to the total riverine runoff and $77 \%$ to the water balance of the lagoon. Water residence time is typically 10-40 days during periods of elevated river discharge and increases to 60-100 days during low discharge (Ferrarin et al., 2008). During elevated discharge, the northern part of the lagoon is typically defined as a transitional riverine-like system with a mixing of brackish, lagoon and riverine waters, while in the summer, there is little input to the lagoon from either sources (Ferrarin et al., 2008). The southern part is more lacustrine and characterized by a relatively closed water circulation with lower current velocities (Ferrarin et al., 2008), where the wind is the main driver (Razinkovas et al., 2005).

The Curonian Lagoon is a naturally productive water basin (Gasiūnaitè et al., 2008; Olenina, 1998). In the second half of the $20^{\text {th }}$ century, agriculture and urban activi- 
ties became major sources of phosphorus and nitrogen, contributing significantly to the eutrophication processes underway (Zaldívar et al., 2008; Žaromskis, 1996). Nowadays the Curonian Lagoon is considered as eutrophic or hyper-eutrophic with recurring spring diatom blooms followed by summer cyanobacteria blooms, a phenomenon that has been reported for several decades (Ūselytè, 1959; Olenina, 1998; Pilkaitytė and Razinkovas, 2006). Large biomass of both emerged and submerged macrophytes, mostly confined in the littoral zones, contributes to the evidence of ongoing eutrophication (Žaromskis, 2002; Sinkevičienè, 2004).

The Curonian Lagoon receives $\sim 98 \%$ of its annual particulate organic matter (POM) inputs from the Nemunas River, the fourth largest river entering the Baltic Sea (Galkus, Jokšas, 1997). Phytoplankton contributes 70\% of the annual POM inputs to the Curonian Lagoon. Brackish inputs entering the lagoon have a 3-6 fold lower concentration of particulate matter relative to inputs from the Nemunas River and therefore their contribution to the
POM budget is relatively small (Jokšas et al., 2005).

Based on water residence time, water chemistry and on the freshwater/brackish water interactions we divided the study area in 5 macro-regions (or ROIs, Regions of Investigation): North, the macro-region interacting with brackish waters, area of $113 \mathrm{~km}^{2}$; Nemunas, the macroregion influenced by Nemunas River discharge, $154 \mathrm{~km}^{2}$; $\mathrm{SE}$, the macro-region influenced by the discharge of other rivers (i.e., Deima, Gilija, Nemunynas and Laukna), 155 $\mathrm{km}^{2}$; SW and Central, the macro-regions where intensive cyanobacteria blooms and scum events were recorded, $264 \mathrm{~km}^{2}$ and $295 \mathrm{~km}^{2}$, respectively (Bresciani et al., 2014) (Fig. 1). All spatial statistical analyses were done pooling available data according to these ROIs.

\section{Data and methods of assessment}

Our investigation focuses mainly on three aspects: i) temporal and spatial variability of CDOM; ii) importance of environmental factors on variation of CDOM in the

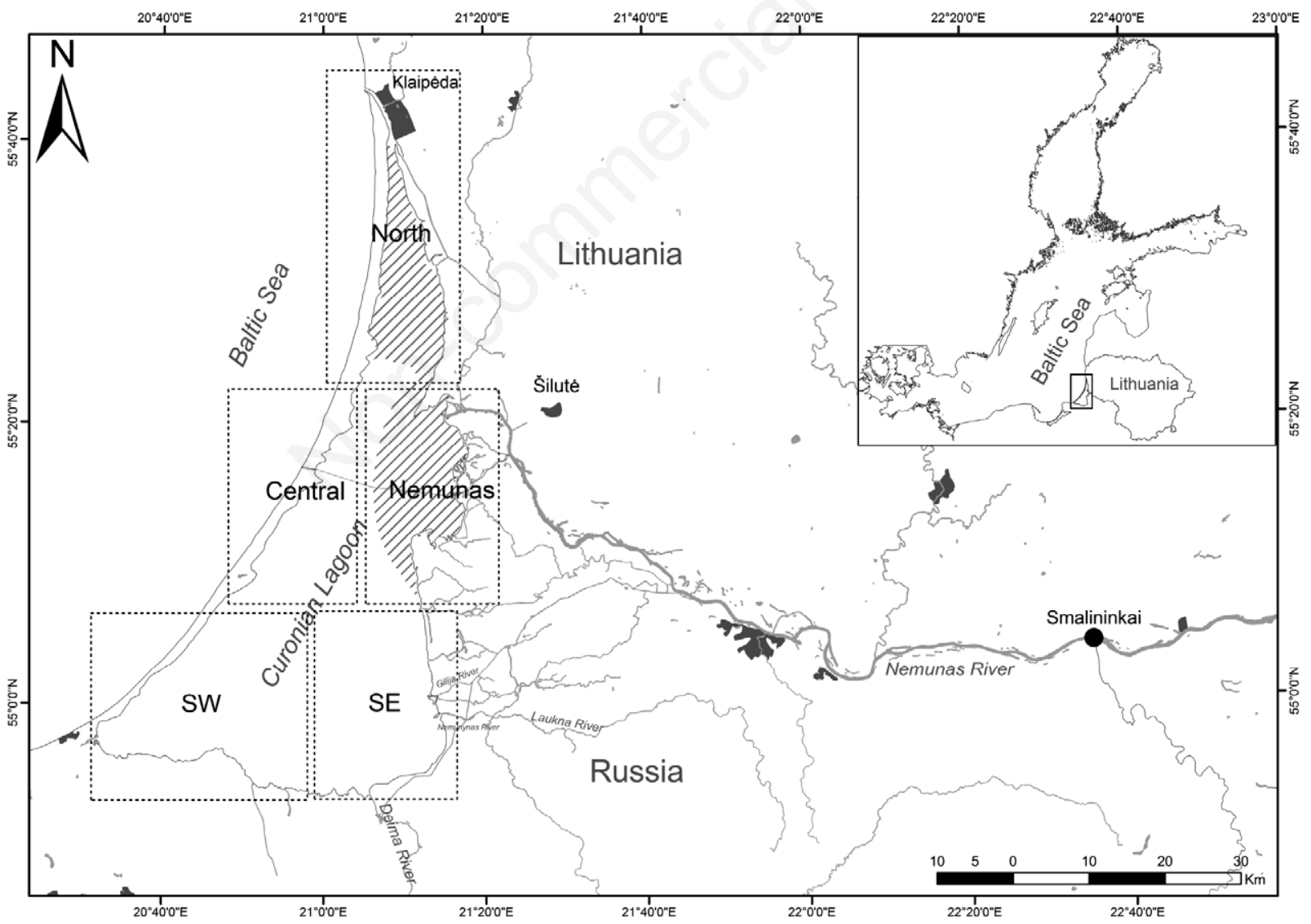

Fig. 1. The study area and five macro-regions of investigation (ROIs): North, Nemunas, Central, SE, SW. Salinity, observations of temperature and wind were measured at the hydrometeorological station located in Klaipeda, precipitation - at the hydrological station located in Šilutè, Nemunas River discharge was measured at Smalininkai. North and Nemunas ROIs are based on typological unites of Water Framework Directive (adapted from Daunys et al., 2007; Langas et al., 2009; Environmental Protection Agency, 2010). 
macro-regions of investigation; and iii) relationship between CDOM and river flow and chlorophyll $a$ (chl-a) concentration (Tab. 1).

\section{Satellite data}

The dataset of 224 Medium Resolution Imaging Spectrometer (MERIS) full resolution (FR) top-of-atmosphere radiance level-1B scenes were processed (Tab. 2). The MERIS instrument provides 12 bit imagery, in 15 bands (from 400 to $900 \mathrm{~nm}$ ) with a spatial resolution of $300 \mathrm{~m}$. MERIS was part of the core instrument payload of the ESA Envisat-1 mission, which operated from 2002 to 2012. Our dataset is composed of images acquired for the period from March to the end of September in the temporal range 2005-2011. Level-1B data were firstly corrected for the difference between actual and nominal wavelengths of the solar irradiance in each channel with the Smile tool (1.2.101 version) of the BEAM VISAT (4.8.1) software provided by Brockmann Consult/ESA.

CDOM concentration (in terms of CDOM absorption coefficient at $443 \mathrm{~nm}$ ) was retrieved with the Boreal lakes processor (Boreal, 1.4.1 version). The latter was validated by match-ups with in situ data and relatively good agreement $\left(\mathrm{R}^{2}=0.69\right.$; $\left.\mathrm{MAE}=0.20 \mathrm{~m}^{-1}\right)$ between in situ and Boreal-derived CDOM absorption was found
(Vaičiūtè et al. 2012). We used the standard cloud mask tool (Cloud Probability Processor, version 1.5.203) available in the BEAM VISAT software to detect and eliminate cloud-contaminated pixels. In order to eliminate the coastal effect on CDOM concentration, three pixels from the shoreline (i.e., $900 \mathrm{~m}$ ) were discarded from the analysis. The retrieval of chl-a concentration was based on Giardino et al. (2010) and Bresciani et al. (2012). In their study MERIS data was corrected for the atmospheric effects with the 6S code (Vermote et al. 1997; Kotchenova et al. 2006). The 6S was run with a maritime aerosol and the aerosol optical thickness at 550 $\mathrm{nm}$, gathered from three AERONET stations (i.e., Gustav Dalen, Tõravere and Belsk) close to the Curonian Lagoon. The 6SV-derived atmospherically corrected reflectance was then converted into Remote Sensing reflectance $\left(\mathrm{R}_{\mathrm{rs}}\right)$ dividing by $\pi$. The band $9(705 \mathrm{~nm})$ to band $7(665 \mathrm{~nm})$ ratio of MERIS-derived $R_{\mathrm{rs}}$ was then computed to estimate chl-a concentration according to Žilius et al. (2014). Based on Bresciani et al. (2014) we also removed all pixels affected by surface scum phenomena. The maps of MERIS-derived CDOM and chla were geocoded and projected to the WGS 84/UTM zone $34 \mathrm{~N}$ coordinate system.

Tab. 1. Data set and statistical approaches applied for different aspects of this paper.

\begin{tabular}{|c|c|c|c|c|}
\hline Aspect & Year & ROI & Data & Statistical analysis applied \\
\hline $\begin{array}{l}\text { Temporal and spatial } \\
\text { variability of CDOM }\end{array}$ & $2005-2011$ & All & $\mathrm{CDOM}^{\circ}$ & $\begin{array}{l}\text { Descriptive statistics (mean, } \\
\text { standard deviation) and } \\
\text { One-way ANOVA }\end{array}$ \\
\hline $\begin{array}{l}\text { Importance of the } \\
\text { environmental factors } \\
\text { on variation of CDOM }\end{array}$ & $2005-2011$ & All & $\begin{array}{c}\mathrm{CDOM}^{\circ} \text {, chl-a } \mathrm{a}^{\circ} \text { discharge of Nemunas } \\
\text { water temperature }{ }^{\#} \text {, salinity } \\
\text { precipitation }{ }^{\#} \text {, wind speed }\end{array}$ & Generalized additive modelling \\
\hline $\begin{array}{l}\text { Relationship between: } \\
\text { - CDOM and river flow; } \\
\text { - CDOM and chl-a }\end{array}$ & $\begin{array}{c}2005-2011 \\
2005-2006,2010-2011\end{array}$ & $\begin{array}{l}\text { Nemunas, SE } \\
\text { Central, SW }\end{array}$ & $\begin{array}{l}\mathrm{CDOM}^{\circ} \text {, discharge of } \\
\text { Nemunas }^{\#}, \text { chl-a }^{\circ}\end{array}$ & $\begin{array}{l}\text { Descriptive statistics (mean, } \\
\text { standard deviation) and } \\
\text { One-way ANOVA }\end{array}$ \\
\hline
\end{tabular}

CDOM, coloured dissolved organic matter; ' satellite derived data; ${ }^{*}$ in situ measured data.

Tab. 2. The number of MERIS images analysed for each month, year and total.

\begin{tabular}{|c|c|c|c|c|c|c|c|c|}
\hline & \multicolumn{8}{|c|}{ Year } \\
\hline & 2005 & 2006 & 2007 & 2008 & 2009 & 2010 & 2011 & Total \\
\hline March & 0 & 0 & 3 & 1 & 2 & 0 & 0 & 6 \\
\hline April & 1 & 0 & 6 & 2 & 8 & 3 & 3 & 23 \\
\hline May & 3 & 3 & 3 & 2 & 3 & 4 & 2 & 20 \\
\hline June & 8 & 9 & 7 & 6 & 5 & 8 & 10 & 53 \\
\hline July & 8 & 9 & 4 & 10 & 6 & 8 & 5 & 50 \\
\hline August & 4 & 4 & 3 & 3 & 8 & 6 & 6 & 34 \\
\hline September & 3 & 7 & 5 & 5 & 6 & 5 & 7 & 38 \\
\hline Total & 27 & 32 & 31 & 29 & 38 & 34 & 33 & 224 \\
\hline
\end{tabular}




\section{In situ data}

The long-term data 2005-2011 during March-September was gathered from the national monitoring program performed by the Department of Marine Research, Environmental Protection Agency of Lithuania. Surface salinity, water temperature and wind speed were measured one to four times per day at a coastal hydrometeorological station located in Klaipeda. The discharge of the Nemunas River was measured at the hydrological station near Smalininkai and precipitation data were received from the hydrometeorological station located in Šilutè (Fig. 1).

\section{Statistical analysis}

Descriptive statistics (mean, standard deviation, median, $25 \%$ and $75 \%$ quartiles) was used to assess temporal and spatial variability of CDOM (Tab. 1). One-way analysis of variance (ANOVA) and Tukey's studentised range test (Quinn and Keough, 2002) was used to verify the hypothesis that CDOM concentration varies significantly in different seasons and five ROIs in the Curonian Lagoon. Data were tested for normality and homogeneity of variances before analysis using graphical tools such as strip charts, boxplots, QQ plots and histograms (Zuur et al., 2007). If data did not meet these conditions, transformations were applied (Sokal and Rohlf, 1995). The same methods were applied for the assessment of relationship between CDOM and river flow, and between CDOM and chl-a.

Nonlinear regression analysis (generalized additive modelling) was used to find the set of environmental factors that explain the variation of CDOM absorption in the Curonian Lagoon. The tested environmental factors were mean chl-a concentration (as estimated from MERIS images), river discharge, precipitation, water temperature, salinity and wind speed. CDOM absorption was log trans- formed in order to meet the assumption of variance equality and normality. Since the river discharge and precipitation were measured in a distance from the lagoon we expected to find the effect on CDOM absorption in the lagoon after some time lag. Therefore, we performed a time lag analysis (cross-correlation) by testing the Spearman rank correlation between CDOM concentration and the river discharge and precipitation for different time-lags: each lag day for 10 days period. For the river discharge the highest and statistically significant correlation $\left(\mathrm{r}_{\mathrm{S}}=0.30, \mathrm{P}<0.05, \mathrm{~N}=224\right)$ was found three days before CDOM concentration was measured and for the precipitation - delay of ten days. Both lags were used in the regression analysis. The multicollinearity was tested among the environmental factors (Zuur et al., 2007) and none of the factors did not highly correlate. The regression analysis was performed with the $m g c v$ package for R, ver. 3.1.0. The residuals of the regression models were analysed by the command gam.chec (Zuur et al., 2007).

\section{RESULTS}

\section{Temporal and spatial variation of CDOM}

The mean CDOM concentration in the spring-summer period of 2005-2011 was $1.47 \pm 0.70 \mathrm{~m}^{-1}$ (Fig. 2). Although the annual mean value of CDOM was not significantly different from year to year, the mean CDOM concentration significantly differed between the spring and summer seasons $(\mathrm{F}=7.25, \mathrm{df}=1, \mathrm{P}<0.05)$ with a multi-year mean CDOM concentration of $1.50 \pm 0.79 \mathrm{~m}^{-1}$ and $1.45 \pm 0.66 \mathrm{~m}^{-1}$ in spring and summer, respectively (Fig. 2). The variability of CDOM in the ROIs of the Curonian Lagoon for the spring and summer periods is given by the multi-year dataset (Fig. 3). Mean CDOM concentration during the spring was significantly different among the ROIs of the

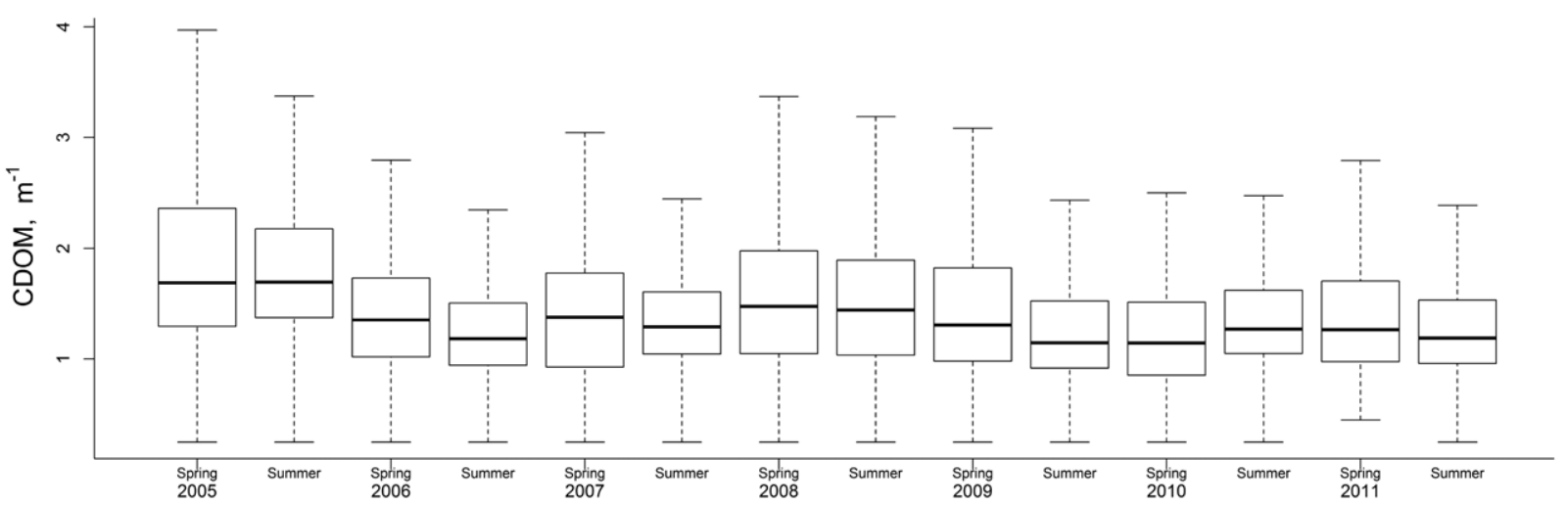

Fig. 2. CDOM concentration $\left(\mathrm{m}^{-1}\right)$ estimated from MERIS images during the period of 2005-2011 in the Curonian Lagoon. The midpoint of a boxplot is the median; the hinges (end of the boxes) are the $25 \%$ and $75 \%$ quartiles (the difference between the hinges is the spread); lines (or whiskers) are 1.5 times the spread. 
Curonian Lagoon $(\mathrm{F}=9.52, \mathrm{df}=4, \mathrm{P}<0.01)$. The highest mean CDOM concentration was observed in the ROIs close to the rivers: Nemunas and Deimena (Dejma) together with Gilija (Matrosovka) and Laukna (Rzhevka). The lowest mean CDOM concentration was observed in the ROIs located in the SW part of the lagoon (Fig. 3).

The mean CDOM concentration significantly differed between the investigated ROIs during the summer period $(\mathrm{F}=5.21, \mathrm{df}=4, \mathrm{P}<0.01)$. Similarly to spring period, the mean CDOM concentration was higher in the regions where the rivers mainly influence water properties (Fig. 3). The lowest mean CDOM concentration was observed in the Northern part, where the Curonian Lagoon is connected with the brackish waters of the Baltic Sea.

\section{Importance of environmental factors to the variation of CDOM concentration in the regions of investigation}

In general, chl-a concentration, river discharge, precipitation and wind speed were the main factors explaining the spatio-temporal variation of CDOM (Tab. 3). Salinity was an important factor exclusively in the North ROI showing negative relationship with CDOM concentration. In this ROI chl-a was more important in spring, whereas the river discharge was important during the summer (Tab. 3).

In the Central and SW ROIs the most important factor was chl-a concentration (Tab. 3). During the spring period, when chl-a concentration ranged from 12 to $83 \mathrm{mg} \mathrm{m}^{-3}$
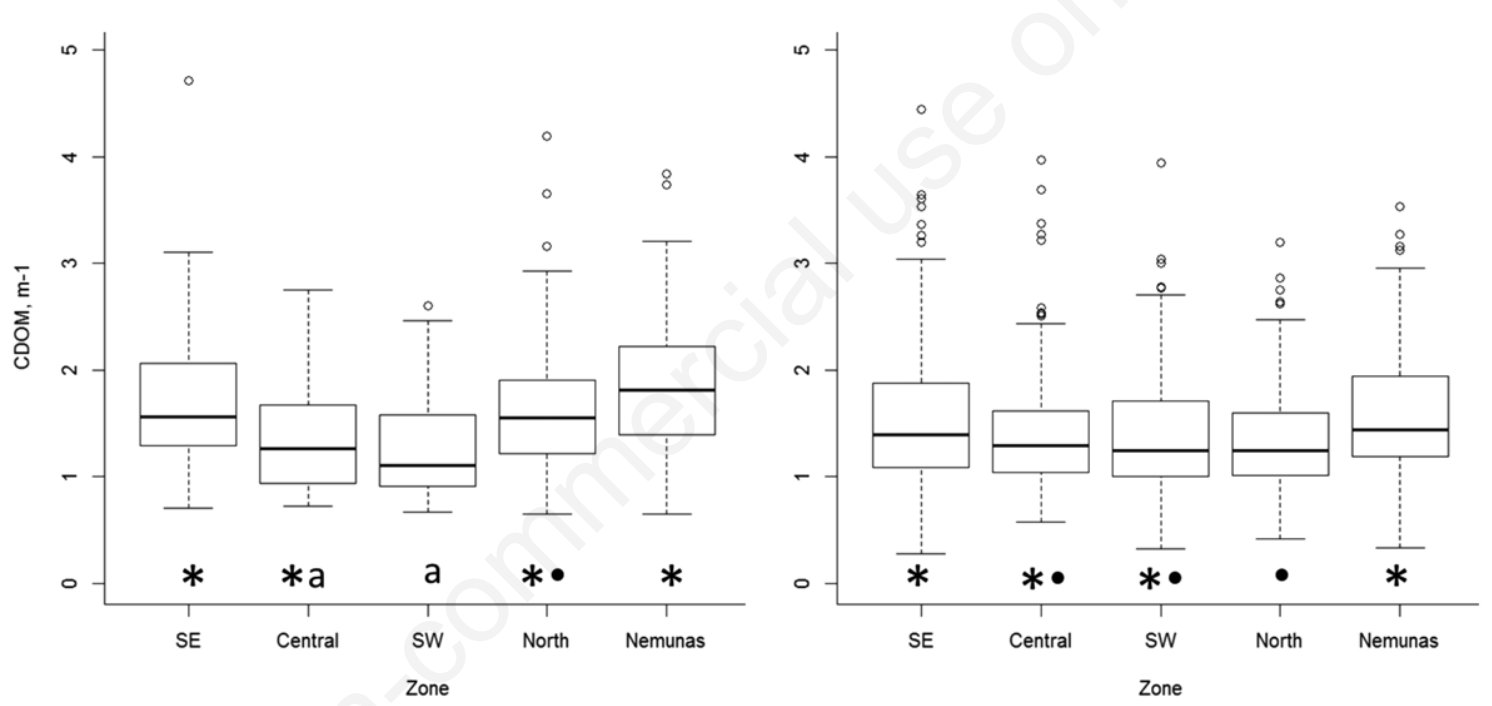

Fig. 3. CDOM concentration in different macro-regions of investigation (ROIs) in spring (left) and summer (right) during the period of 2005-2011 in the Curonian Lagoon. The symbols below indicate homogeneous groups of Tukey's HSD test (N=90). The midpoint of a boxplot is the median; the hinges (end of the boxes) are the $25 \%$ and $75 \%$ quartiles (the difference between the hinges is the spread); lines (or whiskers) are 1.5 times the spread; the points outside the lines are outliers.

Tab. 3. Relative importance (F value) of the explanatory variables for spatial and temporal changes of the concentration of coloured dissolved organic matter in the regions of investigation.

\begin{tabular}{|c|c|c|c|c|c|c|c|}
\hline ROI & Season & $\mathrm{Chl}-\mathrm{a}, \mathrm{mg} \mathrm{m}^{-3}$ & River discharge, $\mathrm{m}^{3} \mathrm{~s}^{-1}$ & Salinity, PSU & Temperature, ${ }^{\circ} \mathrm{C}$ & Precipitation, $\mathrm{mm}$ day $^{-1}$ & Wind speed, $\mathrm{m}$ s \\
\hline North & $\begin{array}{l}\text { Spring } \\
\text { Summer }\end{array}$ & $\begin{array}{l}1.7^{\circ *} \\
1.1^{\circ *}\end{array}$ & $\begin{array}{l}0.8^{\circ *} \\
2.9^{\circ *}\end{array}$ & $\begin{array}{l}0.9^{\#} \\
1.5^{\#^{*}}\end{array}$ & $\begin{array}{c}0.3^{\#} \\
0\end{array}$ & $\begin{array}{c}1.2^{\# *} \\
0\end{array}$ & $\begin{array}{l}0.2^{\#} \\
0.4^{\circ}\end{array}$ \\
\hline Central & $\begin{array}{l}\text { Spring } \\
\text { Summer }\end{array}$ & $\begin{array}{l}0.7^{\circ *} \\
0.8^{\S}\end{array}$ & $\begin{array}{c}0.4^{\circ} \\
0\end{array}$ & $\begin{array}{c}0 \\
0.4^{\S}\end{array}$ & $\begin{array}{c}0 \\
1.0^{\S}\end{array}$ & $\begin{array}{l}1.1^{\# *} \\
0.3^{\#}\end{array}$ & $\begin{array}{c}0 \\
1.5^{\circ *}\end{array}$ \\
\hline SW & $\begin{array}{l}\text { Spring } \\
\text { Summer }\end{array}$ & $\begin{array}{l}1.6^{\circ *} \\
6.1^{\S^{*}}\end{array}$ & $\begin{array}{c}0 \\
0.2^{\circ}\end{array}$ & $\begin{array}{l}0 \\
0\end{array}$ & $\begin{array}{l}0 \\
0\end{array}$ & $\begin{array}{l}1.0^{\# *} \\
0.4^{\S}\end{array}$ & $\begin{array}{c}0 \\
1.8^{\S^{*}}\end{array}$ \\
\hline Nemunas & $\begin{array}{l}\text { Spring } \\
\text { Summer }\end{array}$ & $\begin{array}{c}2.8^{\circ *} \\
0\end{array}$ & $\begin{array}{l}1.6^{\circ *} \\
3.6^{\circ *}\end{array}$ & $\begin{array}{l}0 \\
0\end{array}$ & $\begin{array}{c}3.4^{\# *} \\
0\end{array}$ & $\begin{array}{l}2.2^{\#^{*}} \\
1.0^{\#^{*}}\end{array}$ & $\begin{array}{c}0 \\
1.2^{\circ *}\end{array}$ \\
\hline SE & $\begin{array}{l}\text { Spring } \\
\text { Summer }\end{array}$ & $\begin{array}{l}1.7^{\circ *} \\
1.9^{\S^{*}}\end{array}$ & $\begin{array}{l}1.8^{\circ *} \\
2.1^{\circ * *}\end{array}$ & $\begin{array}{c}0 \\
0.4^{\#}\end{array}$ & $\begin{array}{l}0 \\
0\end{array}$ & $\begin{array}{l}1.0^{\# *} \\
0.1^{\#}\end{array}$ & $\begin{array}{c}0 \\
0.2^{\circ}\end{array}$ \\
\hline
\end{tabular}

ROI, region of investigation; ${ }^{\circ}$ positive relationship; "negative relationship; 'bell-shaped (unimodal) relationship; "statistically significant effects. 
CDOM showed a linear relationship, however in summer when chl-a concentration ranged from 13 to $483 \mathrm{mg} \mathrm{m}^{-3}$ we observed bell-shaped relationship: at the highest chl-a values CDOM concentration significantly decreased (Tab. 3). Precipitation (in spring) and wind speed (in summer) significantly changed CDOM concentration at these macro-regions. In the Nemunas and SE ROIs the most important factor that changed $\mathrm{CDOM}$ concentration were the river discharge and chl-a concentration (Tab. 3). Temperature (especially in spring at the Nemunas ROI), precipitation (in spring) and wind speed (in summer) significantly explained variation of $\mathrm{CDOM}$ concentration at these macro-regions.

\section{Linking CDOM absorption with two main possible sources: river discharge and phytoplankton production}

Over the seven-year period the river discharge generally showed a peak during a spring with some extreme events recorded in summer as well (Fig. 4). In many cases CDOM concentration followed the pattern of the river discharge with a delay of few days. The concentration of chl-a ranged from 4 to more than $400 \mathrm{mg} \mathrm{m}^{-3}$ varying between the investigated years, with mean of $76 \pm 24 \mathrm{mg} \mathrm{m}^{-3}$ (Fig. 5). The intensive bloom was observed mainly in the Central, SW and SE regions, whereas occasionally blooming conditions were identified in the North and Nemunas regions (Fig. 5). In order to test if the collapse of cyanobacteria adds to the budget of organic matter expressed as CDOM we selected: i) two ROIs where chl-a concentration was the most important factor for the CDOM variation; ii) the year when cyanobacteria bloom occur and it was possible to distinguish the periods before the bloom, during the bloom and after the bloom. Analysis was performed with the Central and SW regions and the data from 2005, 2006, 2010 and 2011. The threshold was mean chl-a concentration + stan- dard deviation (i.e., $100 \mathrm{mg} \mathrm{m}^{-3}$ ) of investigation period.

Our analysis confirmed that CDOM absorption differed between three investigated conditions (Fig. 6). The mean CDOM absorption values were significantly higher $\left(1.45 \pm 0.25 \mathrm{~m}^{-1}\right)$ after the cyanobacteria bloom $(\mathrm{F}=5.46$, $\mathrm{df}=2, \mathrm{P}<0.05$ ). Before the algal bloom the mean CDOM concentration was slightly higher $\left(1.31 \pm 0.21 \mathrm{~m}^{-1}\right)$ than during the bloom (mean $1.19 \pm 0.22 \mathrm{~m}^{-1}$ ).

\section{DISCUSSION}

Results from the present study are based on a significant amount (224) of synoptic MERIS images of the study area. The MERIS-derived CDOM concentrations were estimated by applying a reliable tool, the Boreal lakes processor. We provide new insights about the spatial and temporal variations of CDOM in hypertrophic estuarine systems at northern latitudes. The results confirm our general hypothesis that CDOM concentration displays large spatial and temporal variability, depending upon different factors as freshwater inflow, chl-a, water temperature, precipitation and marine influence. Furthermore, we speculate that the regeneration of dissolved organic matter from the sediments and pelagic compartments of the Curonian Lagoon may be quantitatively relevant in the summer period. The large dataset of images we have analysed suggests that CDOM varies by an order of magnitude ( $\sim 1$ to $4.2 \mathrm{~m}^{-1}$, meaning $400 \%$ of variation). Such large variability overlaps that of controlling factors. In the considered system in fact, the Nemunas flow varied in the considered period by a factor 10 , the temperature span from a few to $>20^{\circ} \mathrm{C}$, the chl-a from a few to $>400 \mathrm{mg} \mathrm{m}^{-3}$, the salinity from 0 to 7 PSU.

Prior this study, the seasonal difference of CDOM concentration was investigated by Giardino et al. (2010) in 2009. In their study in situ measurements of CDOM concentration varied between 0.71 and $2 \mathrm{~m}^{-1}$, with higher val-

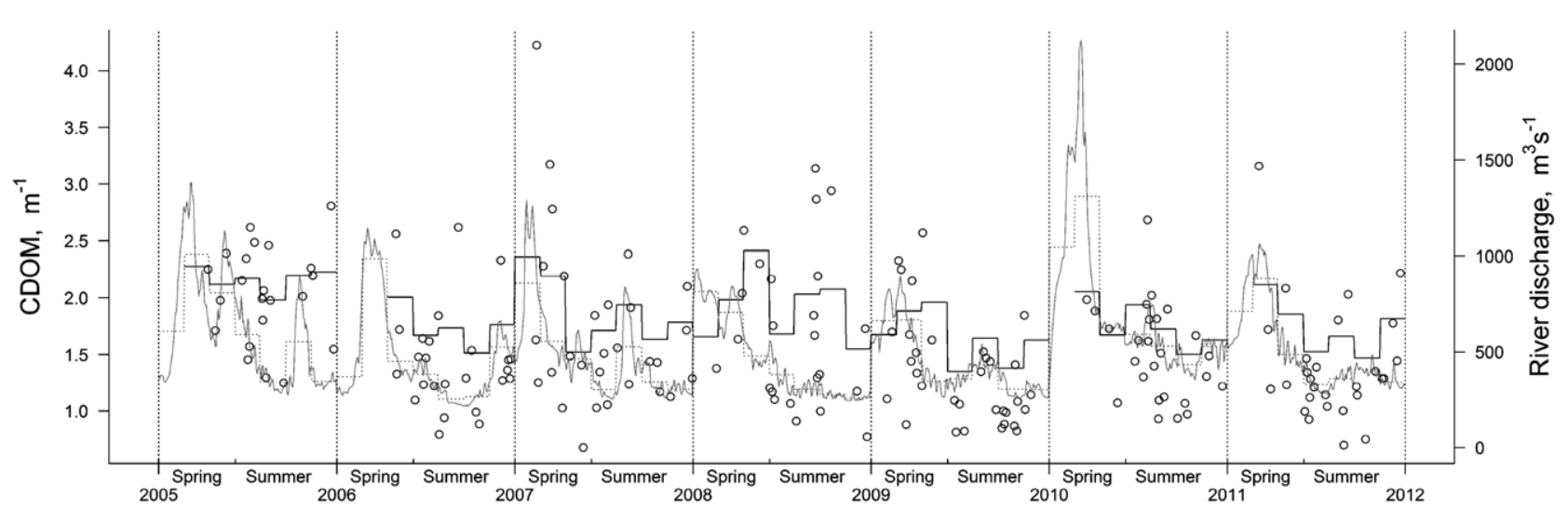

Fig. 4. Averaged daily (circles) and monthly (solid black line) CDOM concentration $\left(\mathrm{m}^{-1}\right)$ of Nemunas and SE ROIs. Daily (solid grey line) and monthly averaged (dashed grey line) discharge $\left(\mathrm{m}^{3} \mathrm{~s}^{-1}\right)$ of the Nemunas River. Investigation period is March-September, $2005-2011$. 
ues in March than in July. In this study the MERIS-derived CDOM concentration varied from 0.6 to $4.4 \mathrm{~m}^{-1}$, with an average of $1.47 \pm 0.70 \mathrm{~m}^{-1}$, which shows a good agreement with Giardino et al. (2010). Other lagoons of the Baltic Sea region are very similar to the Curonian Lagoon from the perspective of CDOM concentration. In the Vistula Lagoon the mean CDOM concentration was approximately $4 \mathrm{~m}^{-1}$ (Kruk et al., 2010) and in the Oder Lagoon CDOM concentration ranged from 1 to $2.2 \mathrm{~m}^{-1}$ (Siegel et al., 2003). Inland water basins like lakes Vänern and Vättern in Sweden represent moderately dominated water basins with mean CDOM concentration of $1.2 \pm 0.5 \mathrm{~m}^{-1}$ and $0.3 \pm 0.1$ $\mathrm{m}^{-1}$, respectively (Alikas, Reinart, 2008). In other lakes of the Europe, CDOM concentration varies in much wider range: from CDOM-poor to extremely dominated by organic matter (Odermatt et al., 2012). In lakes Peipsi and Võrtsjärv located in Estonia, CDOM concentration varied from $2.6 \mathrm{~m}^{-1}$ to $22.33 \mathrm{~m}^{-1}$ and $3.96 \mathrm{~m}^{-1}$ to $15.68 \mathrm{~m}^{-1}$ respectively, with clearly expressed seasonality, which decreases from spring to autumn (Alikas, Reinart, 2008; Toming et al., 2009). In the lakes of Finland, CDOM varied from 0.4 to $15 \mathrm{~m}^{-1}$ (Ylöstalo et al., 2014), whereas the oligotrophic Lake Maggiore (Italy) with mean CDOM of $0.04 \mathrm{~m}^{-1}$ represents a CDOM poor water basin (Giardino et al., 2014). Differently from the inland waters, oceanic waters are described as CDOM poor water masses, where CDOM values are mainly close to 0 (Kirk, 2011). The comparison with other water bodies over the Europe allows us to classify the Curonian Lagoon as moderately CDOM-rich, where organic matter plays a significant role in the ecosystem.

We found empirical evidence that river discharge, the presence of phytoplankton, salinity, water temperature and wind determine the spatial and temporal CDOM concentration in hypertrophic shallow Curonian Lagoon. The importance of salinity to the explained variance of $\mathrm{CDOM}$ concentration in the North ROI suggests a conservative mixing of terrestrial CDOM with the brackish water of the Baltic Sea, as observed in other coastal and estuarine systems (Kowalczuk et al., 2006; Astoreca et al., 2009; Kratzer, Tett, 2009; Klemas, 2012). Strong relationship between these two parameters suggests that CDOM can be one of important indicator describing freshwater intrusion and supply of organic matter in the coastal regions. Strong correlation between CDOM concentration and river discharge indicates the Nemunas River flow being important source of CDOM in the Curonian Lagoon and highlights a strong terrestrial influence on the aquatic system. The same outcome was confirmed by various studies in the Scandinavian region (Erlandsson et al., 2008; Reader et al., 2014) that inland waters and estuaries of the northern Europe (Markager et al., 2011; Toming et al., 2009), as well as other countries (Huang and Chen, 2009). More in details, our data suggest a seasonal shift in the dominance of allochthonous versus autochthonous CDOM sources in this system and an interesting feedback between chl-a and CDOM, varying in the macro-regions of the lagoon and probably reflecting complex patterns of release and uptake, likely regulated by inorganic nutrient availability or limitation.

The increase of CDOM as a result of phytoplankton degradation was shown mainly by experimental setups (Rochelle-Newall, Fisher, 2002; Zhao et al., 2009; Astoreca et al., 2009; Zang et al., 2009) and little by the in situ investigations (D'Sa, 2008; Suksomjit et al., 2009). We found statistically significant difference between CDOM concentrations before, during and after algal blooms event, which confirms that phytoplankton degradation is an important source of CDOM, contributing to the carbon budget in the SW part of the Curonian Lagoon. The correlation between CDOM concentration and chl-a has been determined in various field studies, indicating that phytoplankton accumulation and decomposition are

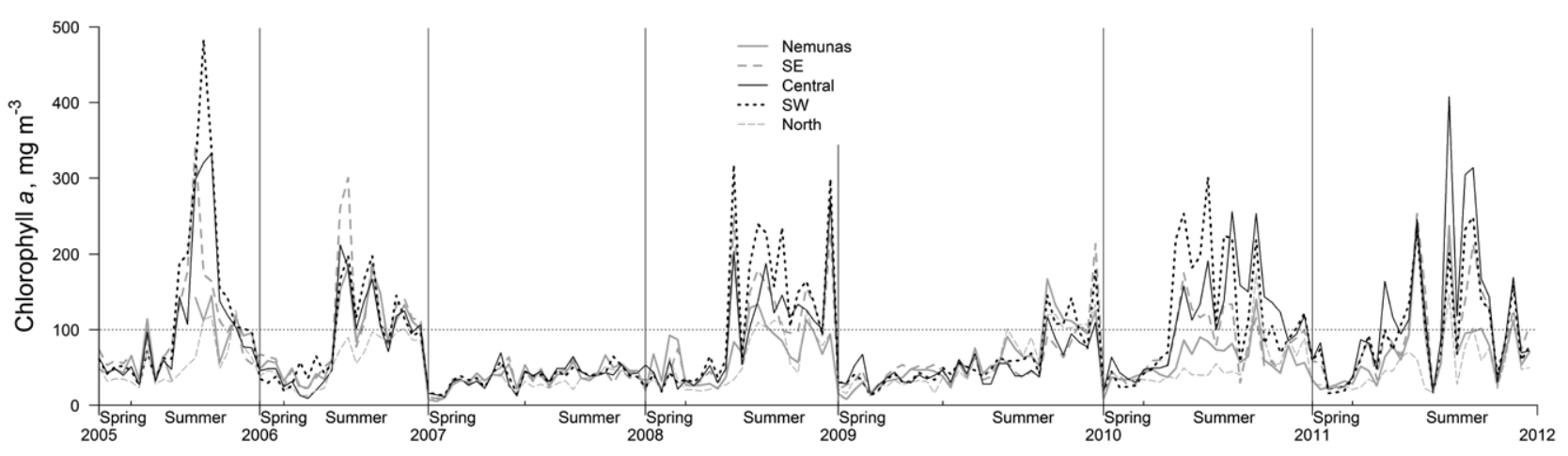

Fig. 5. Chl-a concentration $\left(\mathrm{mg} \mathrm{m}^{-3}\right)$ derived from MERIS images at five macro-regions of investigation (Nemunas, SE, Central, SW, North) during the spring-summer period, 2005-2011. Dashed grey line at $100 \mathrm{mg} \mathrm{m}^{-3}$ indicates the bloom conditions determined for this study - mean chl-a concentration of $76 \mathrm{mg} \mathrm{m}^{-3}+$ standard deviation $24 \mathrm{mg} \mathrm{m}^{-3}$. 

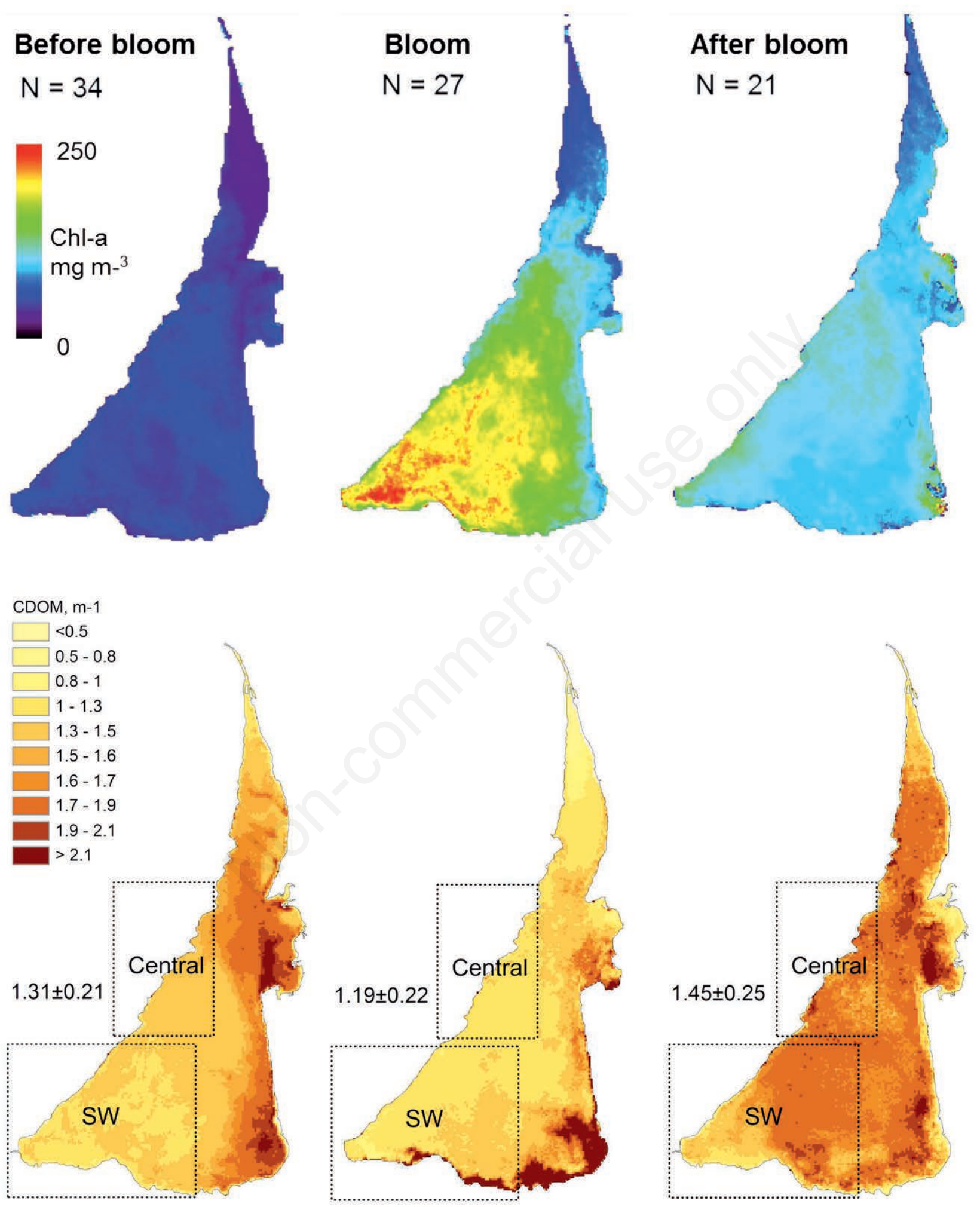

Fig. 6. Maps derived from MERIS images: average chl-a and CDOM before during and after the bloom in 2005, 2006,2010 and 2011. $\mathrm{N}$, number of averaged maps; numbers in the lower panel, mean CDOM concentration of two ROIs: Central and SW. 
contributing sources of CDOM (e.g. Kahru and Mitchell, 2001; Rochelle-Newall, Fisher, 2002, Zhao et al., 2009). In agreement with these previous studies, we have determined by correlation analysis (Tab. 3) that phytoplankton in a hypereutrophic coastal lagoon with high phytoplankton biomass. Furthermore, a bell-shaped trend was found between chl-a and CDOM at extreme chl-a concentrations (up to $400 \mathrm{mg} \mathrm{m}^{-3}$ ), suggesting that $\mathrm{CDOM}$ may control the further growth of cyanobacteria or represent an underestimated food source to phytoplankton during a period when riverine input of nitrogen is limited (Berg et al., 2003, Zhang et al., 2009; Zhang et al., 2013).

\section{CONCLUSIONS}

Seasonal and annual variation of CDOM within a watershed is complex but can be better understood using satellite remote sensing data by giving spatially and temporally much detailed information. We investigated 7 year (2005-2011) covering a period from the ice melting (March) to the late summer (September). We found a seasonal difference between $\mathrm{CDOM}$ concentration $\left(1.50 \pm 0.79 \mathrm{~m}^{-1}\right.$ and $1.45 \pm 0.66 \mathrm{~m}^{-1}$ in spring and summer, respectively). However, seasonal shift in the dominance of allochthonous versus autochthonous CDOM sources in this system and an interesting feedback between chl-a and CDOM is evident. Results from the present study confirm that large spatial and temporal variability in CDOM concentrations in the Curonian Lagoon is caused by different factors: freshwater inflow of Nemunas River, chl-a, water temperature, precipitation and brackish waters of the Baltic Sea. Our research evidently shows that phytoplankton degradation is an important source of CDOM in eutrophic lagoons, and might highly affect the optical properties of the water.

\section{ACKNOWLEDGMENTS}

MERIS data were made available through the ESA project AO-553 (MELINOS) and Category-1 user (ID 7835, IP D. Vaiciute). AERONET data were provided by PIs Giuseppe Zibordi, Olavi Kdrner and Brent Holben. Financial support was provided by project Lithuanian Maritime Sector's Technologies and Environment Research Development (Nr. VP1-3.1-ŠMM-08-K-01-019, D. Vaičiūtè). This study was co-funded by the European Community's Seventh Framework Programme (FP7/20072013) under grant agreement no. 606865, INFORM project.

\section{REFERENCES}

Aarnos H, Ylöstalo P, Vähätalo AV, 2012. Seasonal phototransformation of dissolved organic matter to ammonium, dissolved inorganic carbon, and labile substrates supporting bacterial biomass across the Baltic Sea. J Geophys Res 117:G01004.
Alikas K, Reinart A, 2008. Validation of the MERIS products on large European lakes: Peipsi, Vänern and Vättern. Hydrobiologia 599:161-168.

Astoreca R, Rousseau V, Lancelot C, 2009. Coloured dissolved organic matter (CDOM) in Southern North Sea waters: optical characterization and possible origin. Estuar. Coast. Shelf S. 85:633-640.

Beisner BE, Dent CL, Carpenter SR, 2003. Variability of lakes on the landscape: roles of phosphorus, food webs, and dissolved organic carbon. Ecology 84:1563-1575.

Berg GM, Balode M, Purina I, Bekere S, Béchemin C, Maestrini SY, 2003. Plankton community composition in relation to availability and uptake of oxidized and reduced nitrogen. Aquat. Microb. Ecol. 30:263-274.

Bidigare RR, Ondrusek ME, Brooks JM, 1993. Influence of the Orinoco River outflow on distribution of algal pigments in the Caribbean Sea. J. Geophys. Res. 98:2259-2269.

Blair NE, Aller RC, 2012. The fate of terrestrial organic carbon in the marine environment. Annu. Rev. Marine Sci. 4:401-423.

Blough NV, Green SA, 1995. Spectroscopic characterization and remote sensing of non-living organic matter, pp. 23.45. In: Proc. Dahlem Conf. Wiley, The role of non-living organic matter in the Earth's carbon cycle.

Bresciani M, Adamo M, De Carolis G, Matta E, Pasquariello G, Vaičiūtè D, Giardino C, 2014. Monitoring blooms and surface accumulation of cyanobacteria in the Curonian Lagoon by combining MERIS and ASAR data. Remote Sens. Environ. 146:124-135.

Bresciani M, Giardino C, Stroppiana D, Pilkaitytė R, Bartoli M and Razinkovas A, 2012. Retrospective analysis of spatial and temporal variability of chlorophyll-a in the Curonian Lagoon. J. Coastal Conserv. 16:511-519.

Bushaw KL, Zepp RG, Tarr MA, Schulz-Jander D, Bourbonniere RA, Hodson RE, Miller WL, Bronk DA, Moran MA, 1996. Photochemical release of bio-logically available nitrogen from aquatic dissolved organic matter. Nature 381:404-407.

Coble P, Hu Ch, Gould Jr RW, Chang G, Wood AM, 2004. Colored dissolved organic matter in the Coastal Ocean. An optical tool for coastal zone environmental assessment and management. Oceanography 17:51-59.

D'Sa EJ, 2008. Colored dissolved organic matter in coastal waters influenced by the Atchafalaya River, USA: effects of an algal bloom. J. Appl. Remote Sens. 2:023502.

Dagg M, Benner R, Lohrenz S, Lawrence D, 2004. Transformation of dissolved and particulate materials on continental shelves influenced by large rivers: plume processes. Cont. Shelf Res. 24:833-858.

Dailidienė I and Davuliené L, 2008. Salinity trend and variation in the Baltic Sea near the Lithuanian coast and in the Curonian Lagoon in 1984-2005. J. Marine Syst. 74:20-29.

Daunys D, Olenin S, Paškauskas R, Zemlys P, Olenina I, Bučas M, 2007. Typology and classification of ecological status of Lithuanian coastal and transitional waters: an update of existing system, procurement of services for the institutional building for the Nemunas River basin management. Technical Report for Transition Facility Project No. 2004/016925-04-06: $66 \mathrm{pp}$.

Day HR, Felbeck GJ, 1974. Production and analysis of a humicacidlike exudate from the aquatic fungus Aureobasidium pullulans. J. Am. Water Works Ass. 66:484-488. 
Erlandsson M, Buffam I, Folster J, Laudon H, Temnerud J, Weyhenmeyer GA, Bishop K, 2008. Thirty-five years of synchrony in the organic matter concentrations of Swedish rivers explained by variation in flow and sulphate. Glob. Change Biol. 14:1191-1198.

Ferrarin C, Razinkovas A, Gulbinskas S, Umgiesser G, Bliudžiute L, 2008. Hydraulic regime-based zonation scheme of the Curonian Lagoon. Hydrobiologia 611:133-146.

Galkus A, Jokšas K, 1997. Sedimentary material in the transitional aquasystem. Institute of Geography, Vilnius: 198 pp.

Gasiūnaite ZR, Daunys D, Olenin S and Razinkovas A, 2008. The Curonian Lagoon, p. 197-216. In: U. Schiewer (ed.), Ecology of Baltic coastal waters. Springer-Verlag, Berlin.

Gelfenbaum G, Stumpf RP, 1993. Observations of currents and density structure across a buoyant plume front. Estuaries 16:40-52.

Giardino C, Bresciani M, Pilkaityte R, Bartoli M and Razinkovas A, 2010. In situ measurements and satellite remote sensing of Case 2 waters: Preliminary results from the Curonian Lagoon. Oceanologia 52:197-210.

Giardino C, Bresciani M, Stroppiana D, Oggioni A, Morabito G, 2014. Optical remote sensing of lakes: an overview on Lake Maggiore. J. Limnol. 3:201-214.

Gilbert D, Sundby B, Gobeil C, Mucci A, Tremblay GH, 2005. A seventy-two-year record of diminishing deep-water oxygen in the St. Lawrence estuary: the northwest Atlantic connection, Limnol. Oceanogr. 50:1654-1666.

Haggard KG, Geiger NS, Hayes PM, Milligan AJ, 2013. Suppression of cyanobacterial growth of Aphanizomenon flosaquae by vascular plant decomposition products in Upper Klamath Lake, Oregon. Lake Reserv. Manage. 29:13-22.

Huang W, Chen F, 2009. Sources and transformations of chromophoric dissolved organic matter in the Neponset River Watershed. J. Geophys. Res. 114:G00F05.

Hulatt ChJ, Thomas DN, Bowers DG, Norman L, Zhang CH, 2009. Exudation and decomposition of chromophoric dissolved organic matter (CDOM) from some temperate macroalgae. Estuar. Coast. Shelf S. 84:147-153.

Jokšas K, Galkus A, Stakenienė R, 2005. Geoecological state of the Lithuanian offshore of the Baltic Sea, the lower reaches on Nemunas and the Curonian Lagoon. Acta Zoologica Lithuanica 15:119-123.

Kahru M, Mitchell BG, 2001. Seasonal and nonseasonal variability of satellite-derived chlorophyll and colored dissolved organic matter concentration in the California Current. J. Geophys. Res.-Oceans 106:2517-2529.

Kirk JTO, 2011. Light and photosynthesis in aquatic ecosystems. 3. Cambridge University Press, Cambridge: $662 \mathrm{pp}$.

Klemas V, 2012. Remote sensing of coastal plumes and ocean fronts: overview and case study. J. Coast. Res. 28:1-7.

Kling GW, Kipphut GW, Miller MC, 1991. Arctic lakes and rivers as gas conduits to the atmosphere: implications for tundra carbon budgets. Science 251:298-301.

Kotchenova SY, Vermote EF, Matarrese R, Klemm Jr FJ, 2006. Validation of a vector version of the $6 \mathrm{~s}$ radiative transfer code for atmospheric correction of satellite data. Part i: Path radiance. Appl. Optics 45:6762-6774.

Kowalczuk P, Stedmon CA, Markager S, 2006. Modelling absorption by CDOM in the Baltic Sea from season, salinity and chlorophyll. Mar. Chem. 101:1-11.
Kratzer S, Tett P, 2009. Using bio-optics to investigate the extent of coastal waters: a Swedish case study. Hydrobiologia 629:169-186.

Kruk M, Mroz M, Nawrocka L, Parszuto K, Mleczko M, 2010. Uniseasonal dynamics of main water quality parameters in Vistula Lagoon extracted from Envisat/MERIS geophysical products and in situ measurements. Proc. Hyperspectral 2010 Workshop, ESA publication SP-683.

Langas V, Daunys D, Paškauskas R, Zemlys P, Pilkaitytė R, Razinkovas A, Gulbinukas S, 2009. [Status of transitional and coastal waters, environmental factors and measures to improve environmental status. Part II].[Book in Lithuanian]: 136 pp.

Lomstein BAa, Jensen A-GU, Hansen JW, Andreasen JB, Hansen LS, Berntsen J, Kunzendorf H, 1998. Budgets of sediment nitrogen and carbon cycling in the shallow water of Knebel Vig, Denmark. Aquat. Microb. Ecol. 14:69-80.

Environmental Protection Agency, 2010. [Management plan of Nemunas River basin region].[Report in Lithuanian]: 333 pp.

Markager S, Stedmon CA, Søndergaard M, 2011. Seasonal dynamics and conservative mixing of dissolved organic matter in the temperate eutrophic estuary Horsens Fjord. Estuar. Coast. Shelf S. 92:367-388.

Matsuoka A, Bricaud A, Benner R, Para J, Semṕére R, Prieur L, Bélanger S, Babin M, 2012. Tracing the transport of colored dissolved organic matter in water masses of the Southern Beaufort Sea: relationship with hydrographic characteristics. Biogeoscience 9:925-940.

Mayer LM, Keil RG, Macko SA, Joye SB, Ruttenberg KC, Aller $\mathrm{RC}, 1998$. Importance of suspended particulates in riverine delivery of bioavailable nitrogen to coastal zones. Global Biogeochem. Cy. 12:573-579.

Moran MA and Zepp RG, 1997. Role of photoreactions in the formation of biologically labile compounds from dissolved organic matter. Limnol. Oceanogr. 42:1307-1316.

Nagata T, 2008, Organic matter-bacteria interactions in seawater, p. 207-241. In: D.L. Kirchman (ed.), Microbial ecology of the oceans. 2. J. Wiley \& Sons.

Odermatt D, Gitelson A, Brando VE, Schaepman M, 2012. Review of constituent retrieval in optically deep and complex waters from satellite imagery. Remote Sens. Environ.118:116-126.

Olenina I, 1998. Long-term changes in the Kuršių Marios Lagoon: eutrophication and phytoplankton response. Ekologija 1:56-65.

Paldavičienè A, Mazur-Marzec H and Razinkovas A, 2009. Toxic cyanobacteria blooms in the Lithuanian part of the Curonian Lagoon. Oceanologia 51:203-216.

Pilkaityte R, Razinkovas A, 2006. Factors controlling phytoplankton blooms in a temperate estuary: nutrient limitation and physical forcing. Hydrobiologia 555:41-48.

Quinn GP, Keough MJ, 2002. Experimental design and data analysis for biologists. Cambridge University Press, Cambridge: $520 \mathrm{pp}$.

Razinkovas A, Bliūdžiutė L, Erturk A, Ferrarin C, Lindim C, Umgiesser G, Zemlys P, 2005. Curonian Lagoon: a modelling study - Lithuania, p. 194-222. In: R.C. Russo and R. Lekevicius (eds.), Modelling nutrient loads and response in river and estuary systems. U.S. Environmental Protection Agency, Washington.

Reader HE, Stedmon CA, Kritzberg ES, 2014. Seasonal contri- 
bution of terrestrial organic matter and biological oxygen demand to the Baltic Sea from three contrasting river catchments. Biogeosciences 11:3409-3419.

Riggsbee JA, Orr CH, Leech DM, Doyle MW, Wetzel RG, 2008. Suspended sediments in river ecosystems: Photochemical sources of dissolved organic carbon, dissolved organic nitrogen, and adsorptive removal of dissolved iron. J. Geophys. Res. 113:G03019.

Rochelle-Newall EJ, Fisher TR, 2002. Production of chromophoric dissolved organic matter fluorescence in marine and estuarine environments: an investigation into the role of phytoplankton. Mar. Chem. 77:7-21.

Siegel H, Ohde T, Gerth M, 2003. Preliminary MERIS-validation results for the Baltic Sea. Proc. Envisat - Validation Workshop, ESA Publication SP-531.

Sinkevičienè Z, 2004. Charophyta of the Curonian Lagoon. Botanica Lithuanica 10:33-57.

Sokal RR, Rohlf FJ, 1995. Biometry. 3. WH Freeman \& Co., New York: 880 pp.

Suksomjit M, Nagao S, Ichimi K, Yamada T, Tada K, 2009. Variation of dissolved organic matter and fluorescence characteristics before, during and after phytoplankton bloom. J. Oceanogr. 65:835-846.

Toming K, Arst H, Paavel B, Laas A, Nõges T, 2009. Spatial and temporal variations in coloured dissolved organic matter in large and shallow Estonian waterbodies. Boreal Environ. Res. 14:959-970.

Ūselytė S, 1959. [Phytoplankton of the Kuršių Marios Lagoon, p. 139-163]. In: K. Jankevičius, I. Gasiūnas, A. Gediminas, V. Gudelis, A. Kublickas, I. Maniukas (eds.), [Kuršių Marios: the results of the complex investigations]. [Book in Russian]. Lietuvos TSR Mokslu akademija, Biologijos institutas, Moscow.

Vaičiūte D, Bresciani M, Bučas M, 2012. Validation of MERIS bio-optical products with in situ data in the turbid Lithuanian Baltic Sea coastal waters. J. Appl. Remote Sens. 6:063568.

Ventelä AM, Wiackowski K, Moilanen M, Saarikari V, Vuorio K, Sarvala J, 2002. The effect of small zooplankton on the microbial loop and edible algae during a cyanobacterial bloom. Freshwater Biol. 47:1807-1819.

Vermote EF, Tanrè D, Deizè JL, Herman M, Morcrette JJ, 1997. Second simulation of the satellite signal in the solar spectrum, 6S: an overview. IEEE T. Geosci. Remote 35:675-686.
Williamson CE, Brentrup JA, Zhang J, Renwick WH, Hargreaves BR, Knoll LB, Overholt EP, Rose KC, 2014. Lakes as sensors in the landscape: optical metrics as scalable sentinel responses to climate change. Limnol. Oceanogr. 59:840-850.

Ylöstalo P, Kallio K, Seppälä J, 2014. Absorption properties of inwater constituents and their variation among various lake types in the boreal region. Remote Sens. Environ. 148:190-205.

Zaldívar J-M, Cardoso AC, Viaroli P, Newton A, deWit R, Ibañez C, Reizopoulou S, Somma F, Razinkovas A, Basset A, Holmer M, Murray N, 2008. Eutrophication in transitional waters: An overview. Transitional Waters Monographs $1: 1-78$.

Žaromskis R, 1996. [Oceans, seas, estuaries].[Book in Lithuanian]. Debesija, Vilnius: 293 pp.

Žaromskis R, 2002. [Macrophytes of the Curonian Lagoon and lithodynamic conditions of their habitats].[Article in Lithuanian]. Geografija 38:35-41.

Zhang Y, Liu X, Wang M, Qin B, 2013. Compositional differences of chromophoric dissolved organic matter derived from phytoplankton and macrophytes. Org. Geochem. 55:26-37.

Zhang Y, van Dijk MA, Liua M, Zhua G, Qina B, 2009. The contribution of phytoplankton degradation to chromophoric dissolved organic matter (CDOM) in eutrophic shallow lakes: Field and experimental evidence. Water Res. 43:46854697.

Zhao J, Cao W, Wang G, Yang D, Yang Y, Sun Z, Zhou W, Liang $S, 2009$. The variations in optical properties of CDOM throughout an algal bloom event. Estuar. Coast. Shelf S.82:25-232.

Zhu M, Zhu G, Zhao L, Yao X, Zhang Y, Gao G, Qin B, 2013. Influence of algal bloom degradation on nutrient release at the sediment-water in Lake Taihu, China. Environ. Sci. Pollut. Res. 20:1803-1811.

Žilius M, Bartoli M, Bresciani M, Kataržytė M, Ruginis T, Petkuvienė J, Lubienė I, Giardino C, Bukaveckas PA, de Wit R, Razinkovas-Baziukas A, 2014. Feedback mechanisms between cyanobacterial blooms, transient hypoxia, and benthic phosphorus regeneration in shallow coastal environments. Estuar. Coast. 37:680-694.

Zuur AF, Ieno EN, Smith GM, 2007. Analysing ecological data. Springer, New York: 672 pp. 